\title{
Asymmetry and Governance of Corporate Social Responsible Disclosure in Indonesia
}

\section{Priskila Adiasih and Vania Lianawati}

Business Accounting Program, Petra Christian University, Surabaya, Indonesia

\section{Abstract}

The purpose of this research is to measure the influence of financial leverage, earnings management (modified Jones model), women on board (percentage), and size of the board on the environmental, social, and governance (ESG) disclosure by corporations in Indonesia. The ESG disclosure data used in this research are from Bloomberg database covering the period of 5 years, from 2012 to 2016. The method analysis used in this study is multiple linear regression, while the data is processed using Gretl software. The results show that the financial leverage, earnings management, and women on board (percentage) negatively influence the ESG disclosure practice, while the size of the board influences positively on ESG disclosure. The research limitations are the sample

Corresponding Author:

Priskila Adiasih

priskila@petra.ac.id

Received: 29 January 2019

Accepted: 27 February 2019

Published: 24 March 2019

Publishing services provided by

Knowledge E

(c) Priskila Adiasih and Vania

Lianawati. This article is

distributed under the terms of

the Creative Commons

Attribution License, which

permits unrestricted use and

redistribution provided that the

original author and source are credited.

Selection and Peer-review under the responsibility of the $3 \mathrm{rd}$ ICEEBA Conference Committee. of companies in the Bloomberg ESG disclosure database. This research extends from previous studies conducted on the inclusion of ESG disclosure in Indonesia.

Keywords: corporate governance, disclosure, ESG, Bloomberg

\section{Introduction}

Indonesia is currently entering the era of Industry 4.0 that allows for easier and faster exchanges of information. Industry 4.0 will cause changes in activities that were previously isolated into greater automation, with products that will optimally integrate while data flowing into the global value chain (Strange and Zucchella 2017).

One of the aspects of sustainability that focuses on sustainable development is defined as development which meets the needs of the present without compromising the ability of future generations to meet their own needs. (United Nations World Commission on Environment and Development, 1987). For that reason, the practice of sustainability reporting must result in the management thinking and actions that pursue sustainability (Bradford, Earp, Williams, 2017). In order for external stakeholders benefit from corporate sustainability reporting, including the socially-responsible investors, information presented in the report have to be organized according to the utilization of information to make business decisions. (Mohammed, Ahmed and Xu-Dong Ji, 2017). 
For now, investors are presented with the options to choose between traditional financial-oriented investing and ESG-oriented sustainable investing (Olmedo, Lirio, Torres and Izquierdo, 2017). Good corporate governance practice and financial reporting background will stimulate the performance of capital market to improve investor's confidence (Mohammed et al., 2017).

CSR have increasingly drawn the attention of customers investors, suppliers, and governments from all over the world (Kabir and Thai, 2017). To that end, many companies are getting more interested in reporting their corporate social responsibilies or initiate their CSR activities (Setiawan, 2016). Furthermore, business is also increasingly competitive with easier and more integrated access, resulting in companies trying to get ahead in implementing Corporate Social Responsibility (CSR) (Olmedo et al., 2017).

A good CSR performance is when CSR activities conducted by companies correspond to the stakeholder's expectations. These stakeholder's will in turn give a positive response if they are in agreement with the purposes of a company in implementing CSR (Setiawan, 2016). CSR disclosure becomes an attempt to communicate that the company is not merely established to maximize profits but also to achieve a long-term goal to secure company's sustainability (Isnalita and Narsa, 2017).

There are several decisions that a company has to make in regards to the public disclosure of its CSR information, including balancing its obligation to comply with the regulations, establishing its corporate image and implementing good corporate governance (Setiawan, 2016). Several past researches have employed a different approach in measuring CSR performance, which is by using the scores and ratings from sustainability index, CSR rating institution or CSR information providers. However, few are arguing on the validity and reliability of the tools, including the Socially Responsible Investment (SRI) Metrix, and the Environmental, Social and Governance (ESG) sustainability criteria (Saadaoui and Soobaroyen, 2018).

This research uses ESG parameters in measuring CSR performance as the disclosure requirements and the strength and quality of each institution vary. ESG is believed to be able to predict and assess CSR performance specifically on each company (Bradford et al., 2017).

According to Bajic and Yurtoglu (2018), ESG can capture significant impacts of CSR on companies that drive a correlation between social aspect of CSR and company's value. Systematic ESG information can be used by professional investors as an investment analysis tool. 
This research contributes to the CSR disclosures as it is based on a third-party rating by measuring the extent of disclosures covered by Bloomberg to determine which information are attractive to each related stakeholder in relation to those specific aspects. In Bloomberg methodology, each important data disclosure is measured. ESG disclosure scoring includes CSR disclosure items in relation to the industry (Giannarkis, Konteos and Sariannidis, 2014).

The purpose of this research is to assess factors that influence Environmental, Social and Governance (ESG) disclosure by companies in Indonesia. This research will discuss the Information Asymmetry and Governance of Corporate Social Responsible Disclosure in Indonesia. The indicators used in the research are from Environmental, Social and Governance (ESG) index. ESG indicators that are related to the environmental, social and governance aspects will be further discussed in this research.

\section{Literature Review}

\subsection{Corporate social responsibility (CSR)}

Companies are trying to adopt CSR governance mechanism to achieve their social and environmental goals and to establish legitimacy in the community and business (Wang and Sarkis, 2017). Corporate social and environmental responsibility emerges in many companies as an important element of their corporate strategic direction and component of risk management (Al-Shaer, Salama and Toms, 2017).

Companies utilize different reporting tools in communicating their CSR initiatives to the stakeholder's. However, companies are unable to consider all stakeholder's equally and communicate to them with the same intensity (Giannarkis et al., 2014).

CSR is a concept to manage organizations profitably in a socially and environmentally responsible way to achieve business sustainability and stakeholder satisfaction (Vollero, Palazzo, Siano and Sardanelli, 2018).

Rigorous CSR governance can result in excellent implementation of CSR, through proper allocation of resources and transformation of business structures (Wang and Sarkis, 2017). Results from excellent CSR implementation will help companies in achieving and maintaining their social legitimacy and contributing to the improvements of their business and financial performance (Wang and Sarkis, 2017).

For this reason, in order that sustainability reporting can meet the needs of the companies external people, including the socially-responsible investors, information presented in the report must be able to be used in making business decisions (Bradford, et.al., 
2017). Companies are expected to disclose more information to the public in order that companies can meet the information needs of the stakeholder's. CSR shapes the relation between a company and the stakeholder's because CSR can predict the company value (Bajic and Yurtoglu, 2018).

To achieve the quality of CSR management that can influence a positive market response, corporate governance becomes an important key for a company. Stakeholder's, related corporate goals are related to different expectations that need to be prioritized (Velte, 2016).

\subsection{Environmental, social, and governance (ESG)}

ESG score is used as a complementary to the corporate financial score, improving accuracy in risk performance and assessment (Achima and Borlea, 2015). Viewed as comprehensive information, ESG comprises corporate sustainability performance and represents information that shows whether a company has worked toward the goals of sustainability (Bradford et al., 2017).

Integration of environmental, social and governance (ESG) criteria during an asset evaluation process is widely used by socially-responsible investors. Hence, through ESG, companies are expected to provide detailed information on the companies achievements (Olmedo et al., 2017).

From Bloomberg's ESG scoring, companies can assess their corporate practice in the aspects of Environmental, Social and Governance according to the publicly available data, annual report and sustainability report, direct communication, press release, thirdparty study and the news. The more information disclosed by a company the higher its ESG scores. It displays higher company's commitment toward transparency and accountability (Tamimi and Sebastianelli, 2017).

Environmental performance refers to the use of good environmental practices, such as implementing pollution control measures, making environmental investments, and setting environmental policies. Social performance refers to community investment, such as equal employment opportunities, and other social aspects related to internal and external stakeholders. Governance performance refers to the use of good corporate governance practices, such as CEO separation and the role of board chairman and diversity in board membership, which ensures that companies make decisions for the benefit of shareholders (Husted and Filho, 2016).

In this research, ESG performance is measured by using ESG score, according to data from Bloomberg and corporate annual reports from 2012 up to 2016 . Bloomberg 
measures the extent of CSR disclosure through three different categories, including environmental, social and governance, by using ESG score (Giannarkis et al., 2014).

Different from other literary reviews that consider specific information sources, such as web site or annual report, to build the disclosure index, Bloomberg's methodology combines sources of information more broadly, including CSR reports, annual reports, corporate web sites and Bloomberg's surveys. (Giannarkis et al., 2014). ESG factors offer long- term performance advantages for potential investors once integrated into investing analysis and decision-making (Olmedo et al., 2017).

\subsection{Agency theory}

Agency Theory describes conflicts arising in a company as a result of separation between the owners (principal) and the management (agent) (Eisenhard, 1989). Further, it explains that there is conflict of interests between the principal (shareholders) and the agent (management) (Eisenhard, 1989). Separation between the owners and the management can create agency conflict due to differences in the interests and goals of each individual party.

Conflicts between principal and agent emerge in various forms, including manipulation of financial information, committing accounting frauds and expropriating shareholders' wealth. For that reason, a strong corporate governance mechanism is needed to mitigate the consequences of these conflicts. Corporate governance mechanism requires accounting numbers to be used as tools by the board of directors to monitor and control system (Mohammed et al., 2017).

This is important as shareholder's expect to maximize their profits, while the management might be more interested in their own profits. To that end, the board of directors might need to play an important role in monitoring the management's Agency Theory describes conflicts arising in a company as a result of separation between the owners (principal) and the management (agent) (Eisenhard, 1989).

\subsection{Legitimacy theory}

Legitimacy theory explains that each organization needs to ensure that it has operated within the standards, limitations, or policies set by the communities where it becomes a part of (Deegan, 2000). By applying this theory, a company will voluntarily report all activities, if the management sees that certain activities become the community's interest. 
Based on the legitimacy theory, ESG is not only focused on stakeholders needs and alignment of interests, but also focused on some socially constructed system of norms, values and beliefs (Gray, Kouhy and Lavers, 1995; Martinez-Ferrero et al., 2014).

Corporate governance must ensure that disclosures are done timely and accurately on all material topics on the company, including financial position, performance, ownership and corporate governance. The board of directors will set strict rules, designed to protect the company's interests, in the areas of financial reporting, internal control and risk management (Achima and Borlea, 2015).

According to Rouf (2018), there is a negative relationship between liquidity and leverage of a company. Liquidity is the company's ability to gather short-term obligations. The previous researches, based on legitimacy (Wilmshurst and Frost, 2000; Cormier and Gordon, 2001; Khan, Muttakin, and Siddiqui, 2013), and stakeholder theory (Orlitzky and Benjamin, 2001; Van Der Laan, Van Eesand Van Witteloostuijn, 2008; Al-Shaer et al., 2017), taken from political economy theory, have improved our understanding of corporate social responsibility accounting, and this approach can be complemented by positivist methods, whether routine or more nuanced (Gray and Laughlin, 2012; Al-Shaer et al., 2017).

Companies with increased vulnerability due to their size or industry disclose more information voluntarily as a way to manage. There are many similarities between stakeholder's theory and legitimacy theory that can explain the reason a company might choose to make a certain set of voluntary disclosures legitimacy (Kuo and Yi-Ju Chen, 2013; Al-Shaer et al., 2017).

More specifically, companies can respond to the stakeholder's expectations by integrating disclosure into the company's strategy to reflect the 'real commitment' or its alternative only by doing the minimum to maintain a certain level of legitimacy, which may become tactical or a symbolic legitimacy (Dawkins and Fraas, 2011; Al-Shaer et al., 2017). Financial Leverage

According to (McGuire, Sundgren and Schneeweis, 1988), companies with low CSR level can have an increase in the company's financial risk due to lack of social responsibility initiatives. In contrast, companies that present high level of CSR disclosure face lower financial risks and establish a more stable relationship with the government and financial community.

According to Berger and Humphrey, (1997), managers tend to maintain a low debt level in order to have wider options in making investment decisions. Leverage refers to the amount of debt used to finance company assets and business operations other 
than capital. Leverage can be used as an efficient control mechanism to avoid excessive income reporting practices by management which will ultimately harm the company.

According to Andrade and Kaplan (1998), high corporate leverage causes the company's financial risk to be higher such as financial difficulties, payment failure, debt and bankruptcy risk. According to Jensen (1991) argues that the formation of new regulations and a declining economic crisis have a significant influence on high corporate leverage. Thus, the higher the debt ratio, the greater the risk, and the higher the interest rate (Ghazali, Shafie and Sanusi, 2015).

The level of leverage tends to affect earnings management both positively and negatively. The tendency to avoid violations of debt agreements by companies results in higher earnings management by these companies (Maheswari and Agrawal, 2015).

Branco and Rodrigues (2008) stated that financial leverage influences negatively to the extent of socially responsible disclosures on the internet. Low levels of financial leverage reassure that creditors will not intervening managers decision related CSR disclosure initiatives (Brammer and Pavelin, 2008)

H1: Financial leverage influences negatively to the Environmental, Social and Governance (ESG).

\subsection{Earnings management}

Corporate Social Responsibility is often used as a defensive tool to avoid negative reactions and surveillance from the stakeholders who affected by earnings management, thereby the manager's position in the company allowing managers to acting in their own interest (Prior, Surroca and Tribo, 2008; Martinez-Ferrero et al., 2014). Earnings management can reduces the reputation of companies and leads to loss of reputation of the individual managers responsible for overseeing the reports at the time when accounting scandals or aggressive earnings management practices revealed (Zahra, Priem and Rasheed, 2005; Martinez-Ferrero et al., 2014).

Earnings management is applied when managers use valuations in financial and transaction reporting to change the financial statements in order to mislead some stakeholders on the company's economic performance or to influence the outcome of a contract that depends on the accounting numbers reported (Healy and Wahlen, 1999). The level of CSR disclosure of a company is related to the level of its transparency. Therefore, by employing CSR, the company becomes more transparent and trusted by stakeholders. 
CSR activities have increased with the rapid growth of the stock market which has led to increased demand for transparency (Kabir and Thai, 2017). Earnings management can reduce transparency when related information on earnings management is not fully disclosed. Quality of earnings quality will be considered better if the score of earnings management gets smaller, while the ESG score is higher. Here, social responsibility disclosure plays an important role and a complementary role in reducing information asymmetry (Zhong and Gao, 2017).

Information asymmetry explains the presence or absence of information gaps between the shareholders and the management. Information asymmetry is related to earnings management, which becomes a variable of the quality of earnings. According to Velte (2016), information on sustainability contributes in reducing the occurrence of information asymmetry and the transaction costs due to agency relations between the stakeholders and the company.

A good disclosure of ESG can improve the company's reputation, so that the practice of earnings management carried out by the company is ignored by stakeholders (Martinez-Ferrero et al., 2014)

$\mathrm{H} 2$ : Earnings management negatively influences the Environmental, Social and Governance (ESG)

\subsection{Women on board}

According to Giannarkis et al. (2014), the presence of women directors positively influences CSR disclosure as it brings a unique perspective, experience and work style compared to the male directors. The presence of women can also increase CSR rankings and the company's reputation by communicating an important signal to the investors that display the potential financial performance.

A high percentage of women on board positively influences the level of social disclosure which shows that women are more sensitive to social issues. Thus, the company is sending a signal to the socially-responsible stakeholders on the intention to integrate CSR initiatives into the company's business processes. The board leadership structure tends to significantly influence the level of social disclosure (Giannarkis et al., 2014).

Humphries and Whelan (2017) discover that the proportion of women on the board is lower in countries with high power distance due to lack of regulatory requirements.

In a high power distance culture, recommendations on the gender composition of the board of directors are not considered important, because everyone knows their place. 
Traditional gender roles show that women will not be well represented on company boards. The higher the power distance, the less likely the requirements related to gender composition of the board of directors (Humphries and Whelan, 2017).

H3: Women in board negatively influences the Environmental, Social and Governance (ESG)

\subsection{Size of the board}

Size of the board becomes an important dimension of corporate governance (Ali, 2018). According to Eisenberg, Sundgren and Wells (1998), small sized companies are more efficient than large-sized companies, as the larger size of a company is characterized by a slow bureaucratic decision process; therefore, less effective in overseeing CEO actions.

According to Humphries and Whelan (2017), in a culture of high individualism, the board will appear more legitimate if it can represent the interests of various individuals or stakeholders.

The size of the company tends to influence the level of earnings management both positively and negatively. Larger companies are in a better position to manage profits by using a complex financial structure. On the other hand, companies are also subject to a higher supervision and tend to refrain from engaging in higher earnings management (Maheswari and Agrawal, 2015).

H4: Size of the Board positively influences the Environmental, Social and Governance (ESG)

\section{Research Methodology}

This research is conducted to measure the influence of independent variables, namely earnings management (modified Jones model), women in board (percentage) and size of the board, as well as financial leverage on the dependent variable, namely environmental, social and governance (ESG).

This research uses an analysis model in the form of the following scheme: 


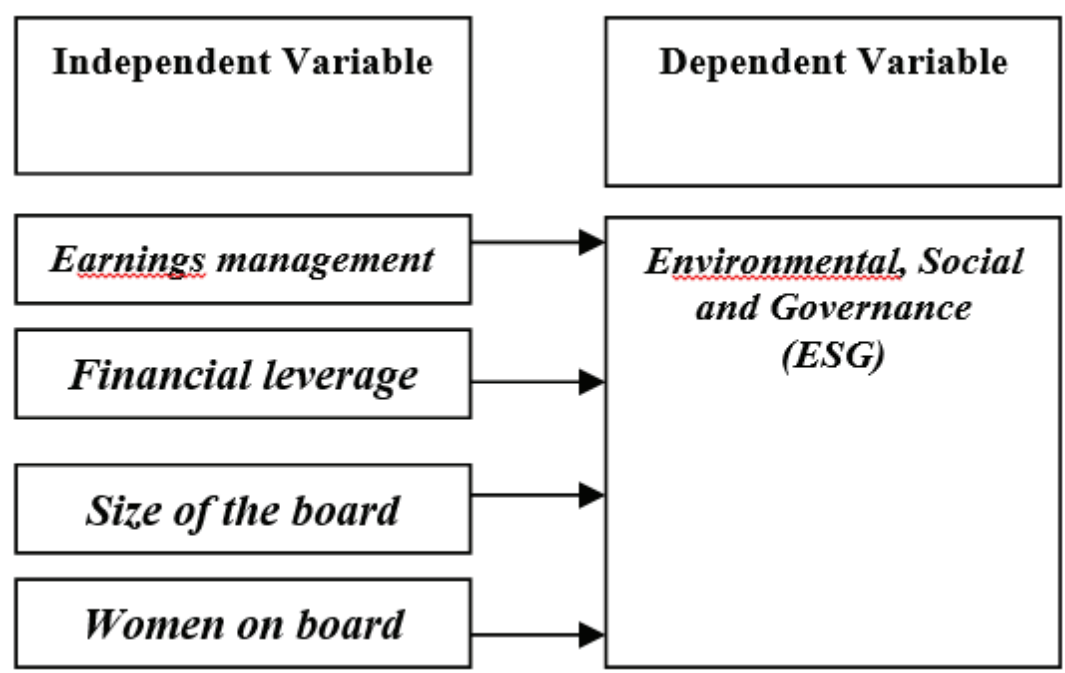

Figure 1: Research model.

\subsection{Sample and data}

The type of data used in this study is quantitative data. Details of data and sources used, including: financial leverage, revenue, total assets, property, plant and equipment, net income, cash flow from operations, total accruals, percentage of women in board, size of the board and ESG score obtained from financial statements of companies listed on the Indonesia Stock Exchange (IDX) through the Indonesian Stock Exchange website (www.idx.co.id) and Bloomberg database. This research uses documentation method to collect company financial report data from 2012 to 2016.

The unit of analysis in this research is the company level, while the model is multiple linear regression. Data testing is required to ensure that available data can be used to test the model that has been formulated in order that the hypothesis that has been proposed can be tested. The data in this study will be analyzed using Gretl and SPSS software.

The research population are companies listed on the Indonesia Stock Exchange (IDX) from 2012 until 2016. The initial population was 80 companies; however, only 27 companies passed the criteria of five years of observation, that is, the period 2012-2016.

The sampling technique used in this study is purposive judgment sampling: 
TABLE 1: Sample criteria.

Sample Criteria
Total companies listed on the Indonesia Stock
Exchange from 2012-2016
Total companies with ESG score
Total companies with incomplete ESG report
Total companies that become samples of the research
Total observation period
Total observation data

Total
582 companies
80 companies
(53) companies
27 companies
5 years
135 observations

\subsection{Equations}

Based on the analysis model, we form a model that will be tested with the multiple linear regression. The analysis model is expressed in simple mathematical equation, as follow:

$$
\mathrm{ESG}=\alpha+\beta_{1} \mathrm{BZ}-\beta_{2} \% \mathrm{WB}-\beta_{3} \mathrm{LEV}-\beta_{4} \mathrm{EM}+\epsilon
$$

Notes:

$$
\begin{aligned}
& \text { ESG }=\text { Environmental, social and governance } \\
& \text { EM = Earnings management } \\
& \% \mathrm{WB}=\% \text { Women on board } \\
& \mathrm{BZ}=\text { Size of the board } \\
& \mathrm{LEV}=\text { Financial Leverage } \\
& \alpha=\text { Constant } \\
& \beta_{1}, \beta_{2}, \beta_{3}, \beta_{4}=\text { Coefficients } \\
& \epsilon=\text { Error }
\end{aligned}
$$

\subsection{Definition variable}

Variable
ESG Score
Financial Leverage
Earnings Management
Women on board
Size of the board

Definition

The extent of three different categories of CSR disclosure (Environmental, Social and Governance)

The scale of average total assets to average total common equity firm's capital structure

Earnings Management modified Jones model

Percentage of women on board

The number of board members 


\subsection{Earnings management (calculation using modified Jones Model)}

In earnings management calculation, we use the Modified Jones Model because this model is considered the best model for detection of earnings management compared to other models and provides the most powerful results (Dechow.PM, Sloan.GG and Sweeney.AP, 1995).

The steps taken in calculating are as follows:

1. Calculate total accruals $=$ Net income - Cash flow from operation

2. Perform the regression equation below

$$
\frac{\mathrm{TA}_{\mathrm{it}}}{\mathrm{A}_{\mathrm{it}-1}}=\alpha\left(\frac{1}{\mathrm{~A}_{\mathrm{it}-1}}\right)+\alpha_{2}\left(\frac{\Delta \mathrm{REV}_{\mathrm{it}}-\Delta \mathrm{REC}_{\mathrm{it}}}{\mathrm{A}_{\mathrm{it}-1}}\right)+\alpha_{3}\left(\frac{\mathrm{PPE}_{\mathrm{it}}}{\mathrm{A}_{\mathrm{it}-1}}\right)+\epsilon_{\mathrm{it}}
$$

Notes:

TA it $=$ Total accrual in year $t$ for company $i$

A it-1 = Total assets in year $t-1$ minus income in year $t-1$ for companies $i$

$\Delta \mathrm{REV}$ it $=$ Revenue in year $t$ minus income in year $t-1$ for company $i$

$\Delta \mathrm{REC}$ it $=$ Receivables in year $t$ minus receivables in year $t-1$ for companies $i$

PPE it $=$ Gross property, plant and equipment

$\alpha, \alpha 2, \alpha 3=$ regression coefficient

\section{Results of Research and Analysis}

\subsection{Descriptive statistics}

TABLE 2: Research's Descriptive Statistics Variables.

\begin{tabular}{l|c|c|c|c|}
\hline Variable & Min & Max & Mean & S.D. \\
\hline ESG Disclosure & 6.61 & 54.1 & 24.2 & 13.5 \\
\hline Financial Lev & 1.16 & 15.0 & 2.34 & 1.62 \\
\hline EM & -0.000264 & 0.000228 & $4.89 \mathrm{e}-021$ & $7.43 \mathrm{e}-005$ \\
\hline Women on Board & 0.00 & 0.333 & 0.0607 & 0.102 \\
\hline Size of the Board & 3.00 & 12.0 & 5.90 & 2.04 \\
\hline Source: Output Gretl. & & & &
\end{tabular}

From Table 2 above, the main dependent variable, that is, ESG Disclosure, of the company research samples has an average value of 24.2 with a standard deviation of 13.5. The highest score on ESG Disclosure is 54, belongs to SMCB in 2014. Meanwhile, the lowest score on ESG Disclosure is 6.6, belongs to BMTR in 2015. 
In the financial leverage independent variable of the research sample companies, the average value is 2.34 with a standard deviation of 1.62 . The highest score on financial leverage is 15,belongs to TBIG 2016. Meanwhile, the lowest score on financial leverage is 1.16, belongs to INTP in 2015.

In the earnings management independent variable of the research sample companies, the average value is $4.89 \mathrm{e}-021$ with a standard deviation of $7.43 \mathrm{e}-005$. The highest score on earnings management is 0,000228 , belongs to AKRA in 2013. Meanwhile, the lowest score on earning management is -0,000264, belongs to HEXA in 2016.

In the women in board independent variable of the research sample companies, the average value is 0.0607 with a standard deviation of 0.102 . The highest score on women in board is 0.333, belongs to PWON in 2014, 2015, 2016 and GGRM in 2013. Meanwhile, the lowest score on women in board is 0 , belongs to 15 companies.

In the women in board independent variable of the research sample companies, the average value is 0.0607 with a standard deviation of 0.102 . The highest score on woman in board is 0.333, belongs to PWON in 2014, 2015, and 2016, as well as GGRM in 2013. Meanwhile, the lowest score of women in board is 0 .

In the size of the board independent variable of the research sample companies, the average value is 5.90 with a standard deviation of 2.04 . The highest score on the size of the board is 12, belongs to JSMR in 2016 and INCO in 2013, 2014. Meanwhile, the lowest score on the size of the board is 3, belongs to PWON, HEXA, SMR, AKRA in 2012-2016 and SCMA in 2012.

\subsection{Panel data regression analysis}

TABLE 3: Ordinary Least Square Model.

\begin{tabular}{|c|c|c|c|}
\hline \multicolumn{4}{|c|}{ Model 1: Pooled OLS, using 135 observations } \\
\hline \multicolumn{4}{|c|}{ Included 27 cross-sectional units } \\
\hline \multicolumn{4}{|l|}{ Time-series length $=5$} \\
\hline \multicolumn{4}{|c|}{ Dependent variable: ESGDISCLOSURE } \\
\hline & Coefficient & p-value & \\
\hline Const. & 16,0939 & $<0.0001$ & $* * *$ \\
\hline FINANCIALLEVERAGE & $-2,16902$ & 0.0007 & $* * *$ \\
\hline EMRES & $-4265,59$ & 0.7530 & \\
\hline WOMENONBOARD & $-33,0299$ & 0.0011 & *** \\
\hline SIZEOFTHEBOARD & 2,57479 & $<0.0001$ & *** \\
\hline
\end{tabular}

Based on Table 3 above, this research model has a $P$-value of 1.21e-09. The value of $P$-value indicates that the model is fit and can be used to test hypotheses. This study 


\begin{tabular}{l|c|}
\hline Adjusted R-squared & 0,282722 \\
\hline P-value(F) & 1,21 e-09 \\
\hline Source: Output Gretl. &
\end{tabular}

uses the 2 best models to be used, namely Pooled Effect Model and Random Effect Model.

Table 4 Random effects

Model: Random-effects (GLS), using 135 observations

Table 4 Hypothesis Testing

Model: Random-effects (GLS), using 135 observations

Hausman test statistic:

$\mathrm{H}=4,43403$ with $\mathrm{p}$-value $=\operatorname{prob}($ chi-square $(4)>4,43403)=0,350441$

(A low p-value counts against the null hypothesis that the random effects model is consistent, in favor of the fixed effects model.)

Figure 2: Hausman test statistic.

Included 27 cross-sectional units

Time-series length $=5$

Dependent variable: ESGDISCLOSURE

TABLE 4

\begin{tabular}{l|c|c|c|c|} 
& Coefficient & Std. Error & p-value & \\
\hline Const. & 16,0939 & 3,65230 & $<0.0001$ & $* * *$ \\
\hline FINANCIALLEVERAGE & $-2,16902$ & 0,620904 & 0.0005 & $* * *$ \\
\hline EMRES & $-4265,59$ & 13524,7 & 0.7525 & \\
\hline WOMEN ONBOARD & $-33,0299$ & 9,92746 & 0.0009 & $* * *$ \\
\hline SIZEOFTHEBOARD & 2,57479 & 0,489634 & $<0.0001$ & $* * *$ \\
\hline Note: $* * *$ & Sig 1\% & & & \\
\hline Source: Output Gretl. & & & & \\
\hline
\end{tabular}

Table 4 presented the hypothesis tests between dependent variable and independent variables. The relation shows that only $\mathrm{H} 2$ not accepted.

\section{Conclusion}

Corporate social responsibility activities are increasingly gaining attention from the investors, customers, suppliers, employees and governments around the world (Kabir and Thai, 2017). Therefore, many companies have shown a higher interest in reporting 
their social responsibilities and initiating CSR activities (Setiawan, 2016). CSR performance is considered well implemented if it is carried out by the company with the purpose to meet the stakeholders' expectations. The advantage gained by companies that implement CSR is that the companies becoming more competitive in the market. CSR becomes a strategy for companies and can serve as an effective communication tool between the companies and stakeholders. This is because not all field activities carried out by companies can be known by the stakeholders.

ESG disclosure comprises sustainability performance and represents information that communicates whether a company is working to achieve sustainability goals (Bradford et al., 2017). From Bloomberg's ESG performance scores, companies can assess their own company practices in the environmental, social, and corporate governance aspects by utilizing publicly available data, annual reports and sustainability reports, direct communication, press release, third-party research and the news (Tamimi and Sebastianelli, 2017).

Results of this research show that financial leverage, earnings management (modified Jones model) and women in board (percentage) negatively influences ESG disclosure, while the size of the board positively influences ESG disclosure. This research is based on the Bloomberg ESG disclosure database. (modified Jones model).

A good disclosure of ESG can improve the company's reputation, so that the practice of earnings management carried out by the company is ignored by stakeholders (Martinez-Ferrero, Banerjee and Gracia-Sanchez, 2014).

The limitations of this study are the sample of companies from Bloomberg's ESG disclosure database. This research extends from the previously conducted research on the inclusion of ESG disclosures in Indonesia.

\section{References}

[1] Achima, M. V. and Borlea, S. N. (2015). Developing of ESG score to assess the nonfinancial. Procedia Economics and Finance, vol. 32, pp. 1209-1224.

[2] Al-Shaer, H., Salama, A., and Toms, S. (2017). Audit committees and financial reporting quality: Evidence from UK environmental accounting disclosures. Journal of Applied Accounting Research, vol. 18, no. 1, pp. 2-21.

[3] Ali, M. (2018). Determinants and consequences of board size: Conditional indirect effects. Corporate Governance: The International Journal of Business in Society, vol. 18, no. 1, pp. 165-184. 
[4] Andrade, G. and Kaplan, S. N. (1998). How costly financial (not economic) distress? Evidence from highly leveraged transactions that become distressed (NBER Working Paper).

[5] Bajic, S. and Yurtoglu, B. (2018). Which aspects of CSR predict firm market value? Journal of Capital Markets Studies, vol. 2, no. 1, pp. 50-69.

[6] Berger, A. N. and Humphrey. (1997). Efficiency of financial institutions: International survey and directions for future research. Journal of Operational Research, vol. 98, pp. 175-212.

[7] Bradford, M., Earp, J. B., and Williams, P. F. (2017). Understanding sustainability for socially responsible investing and reporting. Journal of Capital Markets Studies, vol. 1, no. 1, pp. 10-35.

[8] Brammer, S. and Pavelin, S. (2008). Factors influencing the quality of corporate environmental disclosure. Business Strategy and the Environment, vol. 17, no. 2, pp. 120-136.

[9] Branco, M. C. and Rodrigues, L. L. (2008). Factors influencing social responsibility disclosure by Portuguese companies. Journal of Business Ethics, vol. 83, no. 4, pp. 685-701.

[10] Cormier, D. and Gordon, I. M. (2001). An examination of social and environmental reporting strategies. Accounting, Auditing and Accountability Journal, vol. 14, no. 5 , pp. 587-616.

[11] Dawkins, C. and Fraas, J.W. (2011). Coming clean: the impact of environmental performance and visibility on corporate climate change disclosure. Journal of Business Ethics, 100(2). 303-322.

[12] Dechow, P. M., Sloan, R. G., and Sweeney, A. P. (1995). Detecting earnings management. The Accounting Review, vol. 70, no. 2, pp. 193-225.

[13] Deegan, C. (2002). Introduction: The legitimising effect of social and environmental disclosures-A theoretical foundation. Accounting, Auditing and Accountability Journal, vol. 15, no. 3, pp. 282-311.

[14] Eisenberg, T., Sundgren, S., and Wells, M. T. (1998). Larger board size and decreasing firm value in small firms. Cornell Law Faculty Publications.

[15] Eisenhardt, K. M. (1989). Agency theory: An assessment and review. Academy of Management, pp. 57-74.

[16] Ghazali, A. W., Shafie, N. A., and Sanusi, Z. M. (2015). Earnings management: An analysis of opportunistic behaviour, monitoring mechanism and financial distress. Procedia Economics and Finance, vol. 25, pp. 190-201. 
[17] Giannarkis, G., Konteos, G., and Sariannidis, N. (2014). Financial, governance and environmental determinants of corporate social responsible disclosure. Management Decision, vol. 52, no. 10, pp. 1928-1951.

[18] Gray, R. and Laughlin, R. (2012). It was 20 years ago today: Sgt pepper. Accounting, Auditing and Accountability Journal, vol. 25, no. 2, pp. 228-255.

[19] Halme, M. and Huse, M. (1997). The influence of corporate governance, industry and country factors on environmental reporting. Scandinavian Journal of Management, vol. 13, no. 2, pp. 137-157.

[20] Healy, P. M. and Wahlen, J. M. (1999). A review of the earnings management literature and its implications for standard setting. Accounting Horizons, vol. 13, no. 4, pp. 365383.

[21] Humphries, S. A. and Whelan, C. (2017). National culture and corporate governance codes. Corporate Governance: The International Journal of Business in Society, vol. 17, no. 1, pp. 152-163.

[22] Husted, B. W. and Filho, J. M. D. (2017). The impact of sustainability governance, country stakeholder orientation, and country risk on environmental, social, and governance performance. Journal of Cleaner Production, vol. 155, pp. 93-102.

[23] Isnalita and Narsa, I. (2017). CSR disclosure, customer loyalty, and firm values (study at mining company listed in Indonesia Stock Exchange). Asian Journal of Accounting Research, vol. 2, no. 2, pp. 8-14.

[24] Kabir, R. and Thai, H. M. (2017). Does corporate governance shape the relationship between corporate social responsibility and financial performance? Pacific Accounting Review, vol. 29, no. 2, pp. 227-258.

[25] Khan, A., Muttakin, M. B. and Siddiqui, J. (2013). Corporate governance and corporate social responsibility disclosures: Evidence from an emerging economy. Journal of Business Ethics, vol. 114, no. 2, pp. 207-223.

[26] Maheshwari, Y. and Agrawal, K. (2015). Impact of IPO grading on earnings management. Journal of Financial Reporting and Accounting, vol. 13, no. 2, pp. 142158.

[27] Martinez-Ferrero, J., Banerjee, S., and Gracia-Sanchez, I. M. (2014). Corporate social responsibility as a strategic shield against costs of earnings management practices. Journal of Business Ethics, vol. 133, no. 2, pp. 305-324.

[28] McGuire, J. B., Sundgren, A., and Schneeweis, T. (1988). Corporate social responsibility and firm financial performance. The Academy of Management Journal, vol. 31, no. 4, pp. 854-872. 
[29] Mohammed, N., Ahmed, K., and Xu-Dong, J. (2017). Accounting conservatism, corporate governance and political connections. Asian Review of Accounting, vol. 25, pp. 288-318.

[30] Olmedo, E. E., Lirio, J. M., Torres, M. J., et al. (2017). Integrating multiple ESG investors preferences into sustainable investment: A fuzzy multicriteria methodological approach. Journal of Cleaner Production, vol. 162, pp. 1334-1345.

[31] Orlitzky, M. and Benjamin, J. D. (2001). Corporate social performance and firm risk: a meta-analytic review. Business and Society, vol. 40, no. 4, pp. 369-396.

[32] Prior, D., Surroca, J., and Tribo, J. A. (2008). Are socially responsible managers really ethical? Exploring the relationship between earnings management and Corporate Social Responsibility. Corporate Governance: An International Review, vol. 16, no. 3, pp. 160-177.

[33] Rouf, M. A. (2018). Corporate characteristics and leverage: Evidence from Bangladesh. PSU Research Review, vol. 2, no. 1, pp. 96-104.

[34] Russell, M. (2015). Continuous disclosure and information asymmetry. Accounting Research Journal, vol. 28, no. 2, pp. 195-224.

[35] Saadaoui, K. and Soobaroyen, T. (2018), An analysis of the methodologies adopted by CSR rating agencies, Sustainability Accounting, Management and Policy Journal, vol. 9, no. 1, pp. 43-62.

[36] Setiawan, A. (2016). Integrated reporting: Are Indonesian companies ready to do it? Asian Journal of Accounting Research, vol. 1, no. 2, pp. 62-70.

[37] Strange, R. and Zucchella, A. (2017). Industry 4.0, global value chains and international business. Multinational Business Review, vol. 25, no. 3, pp. 174-184.

[38] Tamimi, N. and Sebastianelli, R. (2017). Transparency among S\&P 500 companies: An analysis of ESG disclosure scores. Management Decision, vol. 55, no. 8, pp. 16601680.

[39] United Nations World Commission on Environment and Development: Our Common Future. (1987).

[40] van der Laan, G., van ees, H., and van Witteloostuijn, A. (2008). Corporate social and financial performance: An extended stakeholder theory, and empirical test with accounting measures. Journal of Business Ethics, vol. 79, no. 3, pp. 299-310.

[41] Velte, P. (2016). Women on management board and ESG performance. Journal of Global Responsibility, vol. 7, no. 1, pp. 98-109.

[42] Vollero, A., Palazzo, M., Siano, A., et al. (2018). Managing CSR communication: A study of legitimacy-seeking strategies adopted by service and product companies. The TQM Journal, vol. 30, no. 5, pp. 621-637. 
[43] Wang, Z. and Sarkis, J. (2017). Corporate social responsibility governance, outcomes, and financial performance. Journal of Cleaner Production, pp. 1607-1616.

[44] Wilmshurst, T. D. and Frost, G. R. (2000). Corporate environmental reporting: A test of legitimacy theory. Accounting, Auditing and Accountability Journal, vol. 13, no. 1, pp. 10-26.

[45] Zahra, S. A., Priem, R. L., and Rasheed, A. A. (2005). The antecedents and consequences of top management fraud. Journal of Management, vol. 31, no. 6, pp. 803-828.

[46] Zhong, M. and Gao, L. (2017). Does corporate social responsibility disclosure improve firm investment efficiency? Evidence from China. Review of Accounting and Finance, vol. 16 , no. 3, pp. 348-365. 